ELŻBIETA KUŻELEWSKA, ADAM R. BARTNICKI

DOI : $10.14746 /$ rie.2017.11.8

Uniwersytet w Białymstoku

\title{
Grupa Wyszehradzka - nowe wyzwania bezpieczeństwa i perspektywy współpracy
}

Grupa Wyszehradzka (V4) istnieje już ponad dwie dekady ${ }^{1}$. Wystarczająco długo by dokonać oceny jej działalności, weryfikacji celów, a także zarysowania nowych perspektyw, szczególnie że obecne środowisko geopolityczne i gospodarcze w niczym nie przypomina tego z początków kształtowania się Grupy. Przez ponad dwadzieścia lat zmieniło się bardzo wiele. Państwa V4 zapomniały o komunistycznym dziedzictwie, są członkami UE i NATO, ich rozwój jest stabilny i - pomimo pojawiających się nowych zagrożeń - relatywnie bezpieczny. Nie jest to rzecz jasna zasługą Grupy Wyszehradzkiej, ale wynikiem intensywnej pracy społeczeństw, w której V4, wbrew deklarowanym u zarania działalności celom, niewiele pomogła. Zarówno współpraca gospodarcza, jak i polityczna były rachityczne, dalece nieodpowiadające możliwościom państw, które na początku lat 90 . XX wieku miały przecież zbieżne dążenia i interesy. Wielokrotnie podkreślana bliskość geograficzna, wspólna historia, podobieństwa kulturowe, a także zbliżony poziom rozwoju gospodarczego pozostały sloganami, za którymi ukrywano fakt, że próba przełożenia tych wartości na wspólnotę interesów zakończyła się de facto porażką.

Celem artykułu jest próba określenia ram współpracy państw Grupy Wyszehradzkiej oraz ukazanie współczesnych trendów i wyzwań stojących przed V4. Omówione zostaną problemy funkcjonowania V4 $\mathrm{w}$ obliczu nowych wyzwań bezpieczeństwa w Europie. Zamierzeniem autorów jest także nakreślenie perspektywy organizacji w zmieniającym się środowisku geopolitycznym. Dla zrealizowania przyjętego celu zastosowano $\mathrm{w}$ tekście metodę komparatystyczną i prognostyczną.

Grupa Wyszehradzka najprężniej działała w początkowym okresie swojego istnienia, tj. na początku lat 90 . ubiegłego wieku. Miało to związek z faktem, że Polska, Węgry i Czechosłowacja dość nieoczekiwanie znalazły się w nowej sytuacji geopolitycznej. Zrywając z uzależnieniem od Związku Socjalistycznych Republik Radzieckich (dalej: ZSRR) intensywnie poszukiwały nowej tożsamości i miejsca w strukturach Zachodu. W tym kontekście zarówno wzajemna współpraca gospodarcza, jak i szeroka płaszczyzna koordynacji polityki zagranicznej wydawały się

${ }^{1}$ W dniu 5 lutego 1991 r. w węgierskim Wyszehradzie podpisano Deklarację o współpracy w zakresie integracji europejskiej. Dokument był parafowany przez prezydenta Republiki Czechosłowackiej Václava Havla, prezydenta Rzeczypospolitej Polskiej Lecha Wałęsę oraz premiera Republiki Węgierskiej Józsefa Antalla. Po rozpadzie Czechosłowacji 1 stycznia 1993 roku Trójkąt Wyszehradzki został przemianowany na Grupę Wyszehradzką. 
istotnymi atutami. Dawała pewne poczucie bezpieczeństwa i wspólnoty interesów w nierozpoznanej jeszcze rzeczywistości międzynarodowej. U podstaw współpracy w ramach Grupy Wyszehradzkiej leżało przekonanie o konieczności wypełnienia luki politycznej, gospodarczej oraz wojskowej, jaka zaistniała po rozpadzie bloku wschodniego i ZSRR (Czyż, 2014, s. 11-12). Integracja państw Grupy z UE i NATO wyhamowała rozwój organizacji (Sobczyk, 2011, s. 175). Nie potrafiono i nie przejawiano woli by opracować nową, wspólną wizję i cele działania, wychodzące poza rytualne zapewnienia o konieczności dalszego pogłębiania współpracy. Zabrakło wspólnych strategii i obszarów realnego współdziałania. Górę brały odmienne interesy, różne definiowanie zagrożeń oraz odmienne spojrzenia na własną rolę w UE. Grupa Wyszehradzka zaczęła zamieniać się w klub dyskusyjny, któremu wyraźnie brakowało jednak moderatora. Co pewien czas pojawiały się co prawda nowe inicjatywy, które były reakcją na doraźne problemy, takie jak współpraca energetyczna (Pronińska, 2013, s. 62-97) czy wspólna modernizacja armii. Niestety, wiele z dyskutowanych projektów nie doczekało się finalizacji.

W swojej historii państwa Grupy Wyszehradzkiej przez niemal dwie dekady nie były w stanie dopracować się wspólnych projektów infrastrukturalnych, przemawiać jednym głosem na forum UE i NATO, wspólnie określać obszary zagrożeń i współpracować w celu ich eliminacji. Gospodarki V4 nie tworzyły pozytywnej synergii, lecz ostro ze sobą rywalizowały głównie o przyciągnięcie inwestycji. Grupa Wyszehradzka nie stworzyła przy tym jakiegoś „znaku towarowego”; była mało rozpoznawalna, nawet $\mathrm{w}$ obrębie społeczeństw państw członkowskich, nie wykształciła ram współpracy na wzór Beneluksu czy Grupy Nordyckiej, nie miała wreszcie wspólnej tożsamości, a cele i interesy członków wydawały się coraz częściej rozbieżne.

Powyższe problemy V4 nie oznaczają jednak, że jej dalsze istnienie jest pozbawione sensu, a samo powołanie Grupy było błędem. Lista realnych sukcesów V4 jest co prawda skromna, ale kilka kwestii warto odnotować. Przede wszystkim w 1992 r. w ramach Grupy zawiązano Środkowoeuropejskie Porozumienie o Wolnym Handlu. Do istotnych elementów funkcjonowania V4 należy zaliczyć współpracę ambasadorów Czwórki w Brukseli oraz powołanie w 2000 r. Funduszu Wyszehradzkiego przyznającego granty i stypendia naukowe. Widoczna jest też solidarna postawa V4 wobec kryzysu migracyjnego. Państwa Grupy Wyszehradzkiej wyrażają sprzeciw wobec wyznaczonych przez Komisję Europejską kwot podziału uchodźców między państwa członkowskie czyli relokacji (Grodzki, 2015, s. 1). Konsekwentnie domagają się też uszczelnienia granic zewnętrznych UE. Po wielu latach zaniedbań V4 przystępuje też do realizacji wspólnych projektów infrastrukturalnych.

W najbliższej przyszłości Grupa powinna stać się narzędziem polityki regionalnej, które umożliwi przeorientowanie szlaków komunikacyjnych i energetycznych z wektora wschód-zachód na wektor północ-południe. Realizacja tak zdefiniowanych celów będzie sprzyjać spójności UE i harmonizacji jej poziomu rozwoju. Można również liczyć, że Grupa znajdzie stabilną płaszczyznę współpracy na niwie energetyki i bezpieczeństwa, chociaż często odmienne postrzeganie zagrożeń i różne interesy strategiczne mogą stanowić tu realną przeszkodę. 


\section{Geopolityka i nowe priorytety}

Państwa Grupy Wyszehradzkiej na początku lat 90. XX wieku znalazły się w zupełnie nowym środowisku geopolitycznym. Z jednej strony, zaskakiwał dość nagły rozpad ZSRR i całego bloku wschodniego z jego ekspozyturami - Układem Warszawskim i RWPG, z drugiej - powstająca Unia Europejska. Krach świata pojałtańskiego oznaczał też, że NATO, które zaledwie kilkanaście miesięcy wcześniej było definiowane jako przeciwnik, teraz przeobrażało się w pożądanego sojusznika. Pełne wyrwanie się z bloku dominacji radzieckiej wcale nie było jednak oczywiste. Na terytorium państw Grupy Wyszehradzkiej nadal stacjonowały wojska rosyjskie. Na terenie Austrii (do 1955 r.), Czechosłowacji i Węgier - Centralna Grupa Wojsk, a w Polsce - Północna Grupa Wojsk. Siły te były rozlokowane m.in. jako narzędzie wywierania nacisku na miejscowe władze ${ }^{2}$. W tych warunkach trudno było przeprowadzić całkowity pivot polityki zagranicznej, zwłaszcza że po stronie struktur zachodnich nie brakowało przywódców patrzących sceptycznie na nową konfigurację międzynarodową (Kupiecki, 2016, s. 174). Jeszcze na początku 1991 r. mało kto zakładał, że może dojść do całkowitego rozpadu bloku wschodniego i samego ZSRR. Co więcej, proces taki postrzegano jako skrajnie niebezpieczny dla bezpieczeństwa europejskiego. Prezydent Francji François Mitterand i premier Wielkiej Brytanii Margaret Thatcher ostrzegali nawet Gorbaczowa przed możliwym rozpadem ZSRR. W tych warunkach współpraca w Grupie Wyszehradzkiej była niezwykle pożądana. Dawała poczucie wspólnoty w nowej rzeczywistości, służyła budowaniu dobrosąsiedzkich stosunków na niwie społecznej i gospodarczej, ale przede wszystkim wspieraniu procesu integracji z UE i NATO. Ponadto w interesie Polski leżało uniknięcie przedwojennych antagonizmów i nieufności wśród państw Europy Środkowo-Wschodniej. Współpraca w ramach V4 wydawała się najlepszym forum neutralizacji animozji i obaw (Grudziński, 2008, s. 154). Podczas szczytu w Pradze w maju 1992 r. podjęto decyzję, że Grupa Wyszehradzka wspólnie złoży wniosek o przyjęcie do Wspólnot Europejskich (WE), co nastąpiło w grudniu 1992 roku.

Od samego początku istnienia V4 można było dostrzec zagrożenia dla funkcjonowania organizacji. Nie zdecydowano się np. na zacieśnienie współpracy obronnej, co wynikało m.in. z obawy, że NATO mogłoby uznać rozwój V4 za alternatywę dla pełnoprawnego członkostwa, ponadto priorytetem każdego z państw było rozwijanie współpracy z Zachodem, nawet kosztem innych członków Grupy. Na przykład najlepiej przygotowana do akcesji z NATO Praga uznawała polityczne wzmacnianie V4 za potencjalne obciążenie na jej drodze do struktur euroatlantyckich (Gniazdowski, Groszkowski, Sadecki, 2012, s. 57). Od 1993 r. następowało wyraźne słabnięcie więzi regionalnych, głównie na skutek kryzysu politycznego na Słowacji oraz postawy rządu Republiki Czeskiej. Słowacja pod rządami premiera Vladimíra Mečiara próbowała występować w roli pomostu między Wschodem a Zachodem. Z kolei ówczesny premier Republiki Czeskiej Václav Klaus sceptycznie oceniał samą ideę współpracy w ramach V4. W jego opinii Czechy nie były częścią Europy Środkowej, ale Zachodniej. W obu przypadkach widać było wyraźną próbę odrzucenia środkowoeuropejskiej tożsamości (Raport, 2013, s. 9).

\footnotetext{
${ }^{2}$ Ostatnie wojska rosyjskie opuściły Polskę dopiero 17-18 września 1993 roku.
} 
Kolejnym problemem stojącym przed państwami V4 była postawa Rosji, która pryncypialnie blokowała rozszerzenie Paktu Północnoatlantyckiego. Na Zachodzie Moskwa była traktowana jako ważniejszy partner i gwarant stabilizacji obszaru postradzieckiego z przyległościami. Również Europę Środkową postrzegano jako jej strefę wpływów (Kużelewska, Bartnicki, Skarzyński, 2015, s. 149). Co prawda już latem 1993 r. prezydent Rosji Borys Jelcyn na spotkaniu z prezydentem RP Lechem Wałęsą powiedział, że kwestia wstapienia Polski do NATO jest sprawą samych Polaków. Deklaracja ta spotkała się jednak z gorącym sprzeciwem w rosyjskim Sztabie Generalnym, jak również zdecydowanej części politycznego establishmentu Moskwy. $\mathrm{W}$ tym okresie (niemal w przeddzień rozprawy z parlamentem) Jelcyn bardzo potrzebował poparcia armii, musiał więc zrewidować swoją politykę (Primakow, 1999, s. 229-230). Pomysłem na zapobiegnięcie rozszerzeniu NATO była wysunięta przez Rosję propozycja przebudowy KBWE w system zbiorowego bezpieczeństwa, w którym Moskwa spełniałaby rolę jego gwaranta (Iwanow, 2002, s. 123). Moskwa proponowała udzielenie państwom Europy Środkowowschodniej krzyżowych gwarancji ze strony NATO i Federacji Rosyjskiej. Odpowiedzią Paktu było wprowadzenie w życie programu „Partnerstwo dla Pokoju”, który dla Rosji i krajów postkomunistycznych miał stworzyć możliwości współdziałania w zakresie stabilizacji i pokojowego rozwoju Europy. Koncepcja „Partnerstwa dla Pokoju”, przyjęta z dużą rezerwą w państwach V4, wskazywała, że USA ciagle nie miały wizji funkcjonowania nowej architektury bezpieczeństwa w Europie Środkowej. Pytania o kryteria, warunki i czas ewentualnego członkostwa państw regionu w NATO pozostały bez odpowiedzi. Moskwa wydawała się ważniejsza. Jeszcze bardziej istotne było jednak, zwłaszcza dla Europy Zachodniej, doprowadzenie do ostatecznego wycofania się wojsk Rosyjskich z terytorium dawnej NRD ${ }^{3}$.

Zaproszenie do Sojuszu stało się impulsem do odnowienia współpracy w ramach Grupy Wyszehradzkiej. Jej efektem było m.in. polityczne wspieranie Bratysławy nadrabiającej zaległości integracyjne. Ostatecznie Słowacja stała się członkiem NATO w 2004 r. Skuteczność udzielonego Bratysławie wsparcia dyplomatycznego wzmocniła wizerunek i prestiż V4. Grupa była wówczas postrzegana jako atrakcyjny klub, którego członkostwo ułatwiało prowadzenie skutecznej polityki. Pośród potencjalnych nowych członków wymieniano Litwę, Słowenię, Rumunię, Bułgarię czy Chorwację. Przywódcy państw Grupy Wyszehradzkiej zdecydowali jednak, że V4 nie będzie powiększana o dalsze państwa (Raport, s. 9).

Przystąpienie państw V4 do NATO i UE spowodowało, że zniknęła jedna z kluczowych przesłanek rozwijania współpracy regionalnej. W 2005 roku rozwiązano sztab brygady polsko-czesko-słowackiej, której formowanie miało służyć wsparciu słowackiej akcesji. Zamiast nadal iść wspólnie, co wydawało się oczywistą potrzebą państw wciśniętych geostrategicznie między Rosję a „starą” UE, każde z państw zaczęło podążać samodzielnie i to różnymi drogami. Było to o tyle nierozsądne, że znacząco osłabiało polityczne możliwości całego regionu. Traconą szansę można

${ }^{3}$ Ostateczne pożegnanie wojsk z udziałem Kohla i Jelcyna nastapiło 31 sierpnia 1994 r. Z terytorium wschodnich Niemiec wycofano 550 tys. żołnierzy, personelu technicznego i członków rodzin. Rosjanie wycofali też ponad 12 tys. czołgów i pojazdów opancerzonych, 4 tys. systemów artyleryjskich, 1,5 tys. samolotów i śmigłowców. 
pokazać porównując skalę potencjału V4 jako liczbę głosów ważonych w Radzie UE (wykres 1).

Wykres 1. Sila Grupy Wyszehradzkiej: liczba głosów w Radzie UE

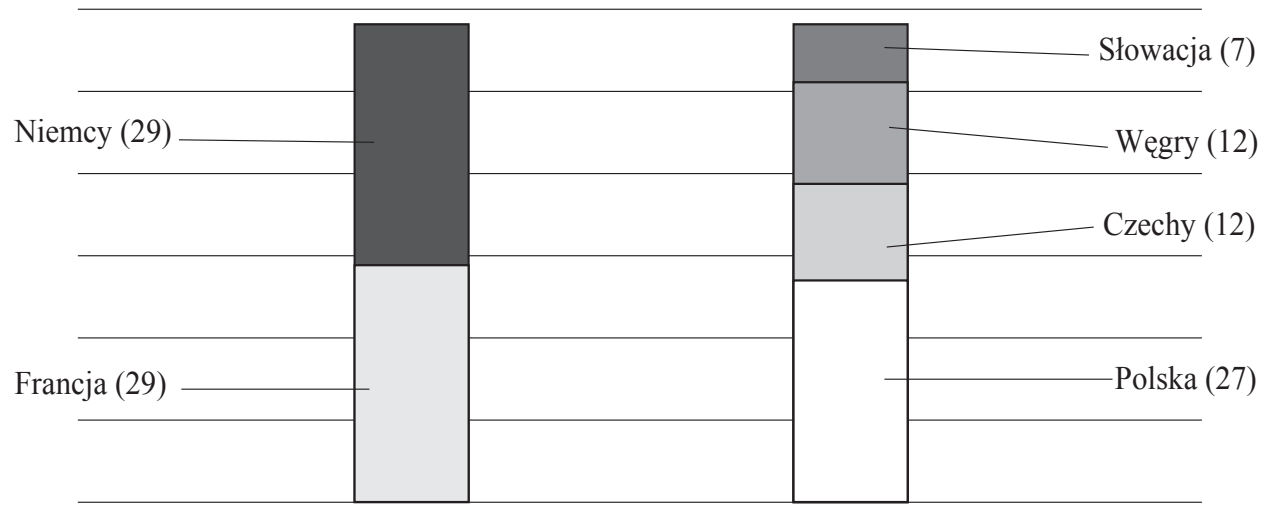

Źródło: Informacja Ministra Spraw Zagranicznych o zadaniach polskiej polityki zagranicznej, Ministerstwo Spraw Zagranicznych RP, Warszawa, 2013, http://www.msz.gov.pl/pl/polityka_zagra-niczna/priorytety_polityki_zagr_2012_2016/expose2/expose_2013/, 16.11.2014.

W Radzie Unii Europejskiej (dalej: RUE), Radzie i Komisji Europejskiej państwa V4 mają po jednym przedstawicielu. Podczas głosowania większością kwalifikowaną w RUE państwa V4 dysponują 58 głosami ważonymi spośród 345 ogółem oraz potencjałem równym ok. 64,1 mln ludności wśród ok. 502,5 mln mieszkańców UE. Z kolei w Parlamencie Europejskim V4 ma razem 108 miejsc spośród 751. Obrazowane liczby stanowią istotny potencjał dla budowania koalicji celem przeforsowania decyzji zgodnych z interesami państw Grupy Wyszehradzkiej lub zablokowania decyzji sprzecznych z nimi (Kubin, 2014, s. 29).

Kryzys współpracy w formule V4 był spowodowany różnym postrzeganiem problematyki bezpieczeństwa, nieco innym wyborem priorytetów polityki zagranicznej, ale też różnym potencjałem państw V4. Polska, kraj zdecydowanie największy i najsilniejszy w Grupie, jest znaczącym graczem z ambicjami do aktywnego współdecydowania o kierunkach rozwoju UE i NATO. Pozostałe państwa Grupy nie posiadają jednak takich aspiracji. Polska, chcąc należeć do grona państw, które odgrywają w UE i NATO wiodącą rolę, zamiast uzgadniać swoje poczynania z trzema mniejszymi krajami, starała się samodzielnie prowadzić rozmowy z przywódcami najważniejszych europejskich państw. Pomysły Warszawy nie zawsze odpowiadały przy tym relatywnie małym partnerom Polski V4. Co gorsza, nie do końca wiadomo, jakie jest polskie stanowisko i polska strategia w wielu kluczowych sprawach, w tym dotyczących przyszłości Grupy Wyszehradzkiej.

Również historia nie sprzyja tworzeniu stabilnych płaszczyzn współpracy w zakresie bezpieczeństwa. W okresie międzywojennym Polska i Czechosłowacja były de facto przeciwnikami na obszarze dawnej monarchii austro-węgierskiej. Kluczowy był konflikt o Śląsk Cieszyński, ale oba państwa różniła także wizja geopolitycznego „ułożenia” regionu. Warszawa rywalizowała z Pragą o pozycję państwa wiodącego 
w regionie, wokół którego tworzyłyby się szersze sojusze. Stworzona w 1933 r. przez Czechosłowację, Rumunię i Jugosławię tzw. Mała Ententa w pewnym sensie przypominała swoimi problemami dzisiejszą Grupę Wyszehradzką. Każde z ówczesnych państw inaczej postrzegało zagrożenia - dla Czechosłowacji były to Niemcy, dla Jugosławii Włochy, a dla Rumunii ZSRR, przy czym percepcja zagrożeń każdego z państw była obca dwóm pozostałym. Podobnie jest dziś. Podczas gdy Polska wskazuję Rosję jako zagrożenie swojego bezpieczeństwa, Węgry i Słowacja otwarcie współpracuja i rozwijają kontakty z Moskwą. Również Czechy sceptycznie patrzą na definiowane przez Warszawę zagrożenia.

Polska próbuje co jakiś czas aktywizować V4. W marcu 2013 roku odbył się szczyt szefów rządów państw Grupy Wyszehradzkiej (Polski - Donalda Tuska, Czech - Petra Neczasa, Słowacji - Roberta Fico i Węgier - Viktora Orbana) z udziałem prezydenta Francji François'a Hollande'a oraz kanclerz Niemiec Angeli Merkel. Poza rytualnymi zapewnieniami o pozytywnych rezultatach spotkania, faktycznie nie przyniosło ono trwałych efektów. Innym pomysłem Warszawy na przyszłość Grupy było rozszerzenie jej formuły o Rumunię, Bułgarię i kraje bałtyckie tzw. „V4+” (Gniazdowski, 2012, s. 45-46). Taki szeroki blok państw od Bałtyku do Morza Czarnego, które łączy podobna droga transformacji, ale przede wszystkim podobne interesy, jeśli chodzi o politykę Unii, bezpieczeństwo energetyczne i postrzeganie problematyki wschodniej, mógłby dać organizacji nowy impuls i podnieść jej realne znaczenie. Dużą niewiadomą jest w tym kontekście forsowany przez Warszawę projekt tzw. Międzymorza oraz ewentualne wsparcie tej inicjatywy przez USA.

Rozdźwięk między państwami V4 unaocznił konflikt rosyjsko-ukraiński. Rozbieżność reakcji Warszawy, Pragi, Bratysławy i Budapesztu na poczynania Moskwy była bardzo wyraźna. Wiele przykładów, które to obrazują, odnaleźć można w obszarze działań energetycznych: np. wsparcie Weggier dla South Stream, zmniejszenie przez Węgrów dostaw gazu na Ukrainę, czy niechętna postawa Słowacji odnośnie do uruchomienia tzw. dużego rewersu gazowego Vojany-Użhorod (uruchomiony ostatecznie 2 września 2014 r.). Nie brak ich również na płaszczyźnie geopolitycznej. Postulat wzmocnienia dodatkowymi siłami NATO tzw. „nowych państw członkowskich” w obliczu rosyjskiej agresji na Ukrainie nie spotkał się ze zrozumieniem Czech i Słowacji. Państwa te nie chciały uczestniczyć w takiej inicjatywie i postulowały jej zawężenie do terytorium Polski i państw bałtyckich. Drastycznie uderza to w politykę Warszawy, która silnie wspiera Ukrainę w jej konflikcie z Rosją jest także za szerokim zaangażowaniem się NATO w zwiększenie bezpieczeństwa regionu poprzez budowę na „wschodniej flance” stałej infrastruktury obronnej Paktu. Brak poparcia przez pozostałych członków V4 postulatów Warszawy formułowanych wobec NATO uderza w strategiczne interesy Polski i niejako kwestionuje możliwość pogłębiania współpracy w obszarze bezpieczeństwa na przyszłość.

Praga i Bratysława także sceptycznie odnoszą się do sankcji wobec Rosji. Zdaniem premiera Słowacji, UE powinna zrezygnować z sankcji, wyrażając tym samym poparcie dla rozejmu na Ukrainie i skupić się na wsparciu dla starań o polityczne rozwiązanie kryzysu i utrzymywanie „otwartego i intensywnego dialogu z Rosją”. Słowacja nie blokuje sankcji, gdyż chce ich większość państw UE, ale stara się ograniczać ich zakres (Gniazdowski, Groszkowski, Sadecki, 2014). Władze Czech w obliczu konflik- 
tu starają się natomiast w pierwszej kolejności bronić interesu czeskich eksporterów, zwłaszcza powiązanego z rynkiem rosyjskim przemysłu maszynowego i ciężkiego. Zarówno Czechy, jak i Słowacja nie zajmuja jednak tak jednoznacznie prorosyjskiego stanowiska jak Węgry.

Odmienna percepcja zagrożeń, jakim dla regionu jest konflikt na wschodzie potencjalnie może utrudniać przyszłą współpracę w zakresie bezpieczeństwa i obrony w ramach V4 (Maciążek, 2014a). Niemniej państwom Grupy stopniowo udaje się wypracować wspólne stanowisko względem problemów bezpieczeństwa energetycznego, zagrożeń migracyjnych, przyszłości wspólnego rynku UE. W coraz większym stopniu przywódcy V4 koordynują swoją politykę w relacjach z silniejszymi partnerami w UE. Następuje refleksja, że pozycja V4 w UE jest porównywalna z pozycją Francji (Francja ma ok. 13\% ludności UE, a kraje V4 - 12,5\%), a w związku z tym zintegrowana Grupa Wyszehradzka ma dość istotną podstawę do forsowania swoich projektów na forum UE.

\section{V4 a problemy bezpieczeństwa i obronności}

Szczyt NATO w Newport we wrześniu 2014 r., a także unijna dyskusja na temat trzeciej fali sankcji wobec Rosji, uwypukliły rozdźwięki w Grupie Wyszehradzkiej. Problemem stało się zajęcie wspólnego stanowiska wobec konfliktu rosyjsko-ukraińskiego, jak też kwestie dotyczące wzmocnienia potencjału Paktu na wschodniej flance. Różnice w percepcji zagrożeń przez członków V4 są dziś na tyle małe, że w ramach NATO mogą one stanowić w miarę spójną, regionalną grupę, ale zarazem na tyle duże, że przy inicjatywach polityczno-wojskowych, wykraczających poza NATO czy UE, trudno liczyć na ich spójność (Gniazdowski, Groszkowski, Sadecki, 2012, s. 58). Grupa od dawna miała zresztą problemy z wypracowaniem wspólnego stanowiska w kwestiach strategicznych; członkowie V4 nie potrafili m.in. stworzyć jednolitego bloku w sprawie wojny w Gruzji w 2008 r., czy instalacji amerykańskiego systemu obrony antybalistycznej (Kałan, s. 2), niemniej jednak choć wcześniej rysowały się różnice podejść do działań, które Sojusz powinien podejmować w zakresie powstrzymywania Rosji w kwestiach dotyczących wzmocnienia NATO, państwa V4 zajmowały zwykle podobne stanowisko. Jeszcze w dniu 18 kwietnia 2012 r. przed szczytem NATO w Chicago państwa V4 wydały wspólną Deklarację „Responsibility for a strong NATO” (Odpowiedzialność na rzecz silnego NATO), w której deklarowano m.in. potrzebę ,wzmacnianie politycznego zaangażowania” oraz „zdolności obronnych NATO”. Państwa Grupy Wyszehradzkiej opowiadały się za prowadzeniem ćwiczeń usankcjonowanych przez artykuł 5 Traktatu Północnoatlantyckiego (wspólna obrona), w tym ćwiczeń „na naszych terytoriach”.

Polska, Czechy, Słowacja i Węgry analizują też kilka obszarów współpracy w ramach inicjatyw smart defence $e^{5}$ NATO oraz pooling and sharing ${ }^{6}$ UE: szkolenie pi-

${ }^{4}$ Pełny tekst: http://www.msz.gov.pl/resource/ee1c8d3f-ff70-4283-87ba-8b1cc2c388cb, 10.11.2014.

5 Smart Defense (,,inteligentna obrona”) zakłada przejmowanie zadań obronnych państw członkowskich o ograniczonych zdolnościach w jednej dziedzinie przez inne państwa sojuszu. Chodzi o wspólne, wielonarodowe projekty łatwiejsze do udźwignięcia przez budżety narodowe.

${ }^{6}$ Inicjatywa łączenia i wspólnego wykorzystania zdolności wojskowych zapoczątkowana na spotkaniu ministrów obrony UE w Gandawie we wrześniu 2010 roku. 
lotów, wspólna logistyka i zabezpieczenie medyczne, zwalczanie improwizowanych urządzeń wybuchowych, obrona chemiczna, biologiczna, radiologiczna i nuklearna (CBRN), wspólne opracowanie opancerzonych wozów bojowych, amunicji średniego i dużego kalibru, indywidualnych systemów wyposażenia i uzbrojenia żołnierza, a także zintegrowanych systemów wsparcia dowodzenia oraz zobrazowania pola walki (Lorenz, 2013, s. 1-2). Główne tezy deklaracji powtórzone zostały w komunikacie końcowym ze spotkania ministrów obrony Grupy Wyszehradzkiej w Litomierzycach, które odbyło się 3-4 maja 2012 roku. Państwa V4 zobowiązały się zacieśniać współpracę w dziedzinie rozwoju zdolności, wskazując jej potencjalne obszary, w tym obronę przed bronią masowego rażenia, logistykę, szkolenie pilotów śmigłowców oraz symulatory dla kontrolerów lotniczych. Zapowiedziano poszukiwanie możliwości harmonizacji planowania obronnego. Grupa Wyszehradzka ma obecnie znikomy wspólny mianownik w kwestiach bezpieczeństwa i obronności. Państwa V4 są co prawda w NATO, ale mimo negatywnych zmian zachodzacych w Pakcie w pierwszej dekadzie XXI wieku (ekspedycje kosztem obrony państw członkowskich) nie podjęły próby stworzenia dodatkowych pól, na których możliwa byłaby ściślejsza integracja ich polityk bezpieczeństwa. Nie udało się też w obrębie GW wdrożyć żadnych projektów wzmacniających region. Wynikało to zarówno z różnic politycznych (postrzegania zagrożeń), próby obrony swojej „,suwerenności strategicznej” wobec partnerów V4, braku woli politycznej, co wynikało z ograniczonego zaufania do partnerów, jak i z różnicy potencjałów militarnych. Spośród państw V4 Polska przeznacza na obronę narodową najwięcej zarówno w liczbach bezwzględnych, jak i w odniesieniu do produktu krajowego brutto $^{7}$, ma też zdecydowanie największą i relatywnie nowoczesną armię (tabela 1).

Tabela 1

Potencjal militarny państw V4 w 2015 r.

\begin{tabular}{||l|c|c|c|c||}
\hline \multicolumn{1}{|c|}{ Wyszczególnienie } & Polska & Czechy & Słowacja & Węry \\
\hline \multicolumn{1}{|c|}{1} & 2 & 3 & 4 & 5 \\
\hline Liczba ludności & 38383809 & 10162921 & 5488339 & 9939470 \\
\hline $\begin{array}{l}\text { Powierzchnia państwa w tys. } \\
\mathrm{km}^{2}\end{array}$ & 312685 & 78867 & 49035 & 2185 \\
\hline PKB w \$ USA & 792400000000 & 291700000000 & 130500000000 & 193600000000 \\
\hline Budżet sił zbrojnych w \$ USA & 9360000000 & 2220000000 & 1025000000 & 104000000 \\
\hline Personel wojskowy w tys. & 120 & 21 & 13,5 & 20 \\
\hline Lotnictwo & 475 & 109 & 49 & 30 \\
\hline Helikoptery & 263 & 54 & 17 & 12 \\
\hline Czołgi & 1063 & 123 & 30 & 155 \\
\hline Pojazdy wojskowe & 3110 & 586 & 530 & 1508 \\
\hline Artyleria & 257 & 54 & 26 & 30 \\
\hline
\end{tabular}

7 Węgry - do 2022 roku zwiększą budżet obronny z obecnego poziomu 0,8\% PKB do 1,39\% PKB; Słowacja - do 2020 roku zwiększy budżet obronny z obecnego poziomu 1,04\% do poziomu 1,6\% PKB; Czechy - do 2020 roku zwiększy budżet obronny z obecnego poziomu 1,1\% do 1,4\% PKB; Polska - w 2016 roku zwiększono budżet obronny z obecnego poziomu 1,96\% do 2\% PKB. Dane w oparciu o: M. Gniazdowski, J. Groszkowski, A. Sadecki, Państwa Grupy Wyszehradzkiej, w: W regionie siła? Stan i perspektywy wspótpracy wojskowej wybranych państw obszaru od Morza Battyckiego do Morza Czarnego, pod red. J. Gotkowskiej, O. Osicy, OSW Warszawa 2012. 


\begin{tabular}{||l|c|c|c|c||}
\hline \multicolumn{1}{|c|}{1} & 2 & 3 & 4 & 5 \\
\hline $\begin{array}{l}\text { Artyleria samobieżna } \\
\text { Samobieżne wyrzutnie rakie- } \\
\text { towe }\end{array}$ & 443 & 97 & 16 & 0 \\
\hline Flota (liczba jednostek) & 240 & 0 & 26 & 65 \\
\hline
\end{tabular}

Źródło: Opracowanie własne na podstawie globalfirepower.com, 18.05.2016.

W dniu 6 marca 2013 r. Polska, Czechy, Słowacja i Węgry podpisały list intencyjny w sprawie utworzenia Wyszehradzkiej Grupy Bojowej, działającej w ramach Wspólnej Polityki Bezpieczeństwa i Obrony UE. W jej skład weszło 3,9 tys. żołnierzy, z czego połowę stanowią Polacy. Czechy wystawiły 800 żołnierzy, Węgrzy ok. 600, a Słowacja 450 (Zieliński, 2013, s. 308). Szczególną rolę w tej inicjatywie odgrywa Polska, będąca tzw. państwem ramowym, na którym oparta jest zasadnicza działalność grupy bojowej. Gwoli ścisłości - decyzję o powołaniu Grupy Bojowej podjęto już w 2009 r. podczas spotkania ministrów obrony Grupy Wyszehradzkiej. Jako przesłanki jej utworzenia wskazano głównie integrację dla bezpieczeństwa (Ciupiński, 2014, s. 116). Grupa Bojowa państw Grupy Wyszehradzkiej rozpoczęła dyżur bojowy w dniu 1 stycznia 2016 r., który trwał do 30 czerwca 2016 roku. Grupa przewidziana jest do misji stabilizacyjnych i prewencyjnych. Niemniej, istotnym wyzwaniem dla tej współpracy może być ograniczanie wydatków wojskowych ze strony partnerów Polski (Czaputowicz, 2013, s. 33). Ponadto, doświadczenie podpowiada, że od momentu powołania w 2007 r. grupy bojowe UE nie zostały użyte. Państwa nie są zainteresowane zwiększeniem zaangażowania i przejęciem większej odpowiedzialności za bezpieczeństwo (Czaputowicz, 2014, s. 23).

Współpraca $w$ ramach NATO układa się całkiem sprawnie, przykładem czego mogą być inicjatywy z udziałem państw V4: Centrum Szkolenia Sił Połączonych, 3. Batalion Łączności, Wielonarodowy Batalion Policji Wojskowej czy Centrum Doskonalenia Policji Wojskowej (Gizicki, 2014, s. 60).

Bardzo nieudane są, jak dotąd, próby nawiązania bliższych relacji w obszarze współpracy wojskowo-technicznej V4, tj. wspólnej modernizacji sił zbrojnych, serwisowania sprzętu czy tworzenia zupełnie nowych konstrukcji. Jest to o tyle niezrozumiałe, że przemysł zbrojeniowy krajów Grupy Wyszehradzkiej bardzo wiele łączy, przede wszystkim dziedzictwo postsowieckich technologii wojskowych. Warto tu także przypomnieć udane doświadczenia współpracy z przeszłości przy produkcji transporterów kołowych OT-64/SKOT (Bębenek, 2014, s. 12) czy gąsienicowego transportera opancerzonego Topas. Oba pojazdy były wykorzystywane przez armię polską i czechosłowacką. Wydawało się, że przynajmniej w sprawach modernizacji sprzętu konstrukcji radzieckiej możliwe będzie nawiązanie bliższej współpracy. Dotyczyło to głównie modernizacji czołgów T-72, które były na wyposażeniu wszystkich armii V4 a wymagały gruntownej i kosztownej modernizacji. Duże znaczenie przypisywano także porozumieniu o współpracy w zakresie modernizacji śmigłowców Mi-24, zawartemu w 2002 roku. Zgodnie z nim, w Polsce miałoby zostać zmodernizowanych około 100 śmigłowców będących na stanie sił zbrojnych V4 ${ }^{8}$. Polska przejawiała chęć

${ }^{8}$ Porozumienie między Rządem Rzeczypospolitej Polskiej, Rządem Republiki Czeskiej, Rządem Republiki Węgierskiej oraz Rządem Republiki Słowackiej dotyczące współpracy w zakresie 
zakupu od Rosji silników i przekładni do Mi-24, a resztę prac, które miałyby unowocześnić śmigłowce i dostosować je do standardów NATO, Polacy mieliby wykonać samodzielnie. W 2003 roku z projektu wycofali się Czesi (Raport, 2012, s. 57). W tym wypadku o całkowitym fiasku zadecydowała jednak postawa Rosji, która odmawiała Polsce przekazania licencji i faworyzowała rozmowy bilateralne z poszczególnymi państwami V4.

Równie źle układała się współpraca w zakresie zakupu nowego uzbrojenia i sprzętu. W tym wypadku ewentualne korzyści ze wspólnego negocjowania kontraktów ustępowały partykularnym interesom poszczególnych państw tj. ich oczekiwaniom offsetowym - które mogły zapewnić zarówno nowe miejsca pracy w rodzimym przemyśle zbrojeniowym, jak i transfer technologii. Najbardziej jaskrawym przykładem tej tendencji był brak współpracy w zakresie wspólnego zakupu nowych myśliwców: Polska zakupiła F-16, Węgry i Czechy wydzierżawiły JAS 39 Gripen, a Słowacja pozostała przy samolotach MiG i otrzymała dwanaście nowych MiG-29A/UB w ramach rozliczenia długów z Rosją (Raport, 2012, s. 57-58).

Nowe otwarcie we współpracy w dziedzinie uzbrojenia i sprzętu wojskowego miało nastapić w 2009 roku, gdy powołano cztery grupy robocze koordynowane przez poszczególne państwa: obrona przed bronią masowego rażenia (Czechy); projekt „Żołnierz XXI wieku” (Polska); modernizacja obrony powietrznej i rakietowej (Słowacja); transport strategiczny (Węgry). Współpraca objęła konsultacje, wymianę informacji, harmonizację regulacji krajowych i tworzenie dokumentów koncepcyjnych. Nie udało się jednak doprowadzić do wspólnych projektów badawczych, modernizacji i akwizycji oraz wspólnego wykorzystania ośrodków szkoleniowych. Prace grup roboczych nie wykroczyły zresztą poza poziom konsultacji i deklaracji. Pojawiają się jednak kolejne plany i koncepcje współpracy w kwestii modernizacji technicznej sił zbrojnych. Planowane jest m.in. wspólne opracowanie nowej stacji radiolokacyjnej, w celu zastąpienia radarów typu P-37 produkcji ZSRR (Palowski, 2014). Przewiduje się zakup łącznie 11 stacji radiolokacyjnych dla Czech, Węgier i Słowacji, osadzonych na podwoziu samochodów ciężarowych Tatra. Ostatecznie projekt zakończył się fiaskiem. W grudniu 2016 r. Minister obrony Czech Martin Stropnický poinformował, że czeskie siły zbrojne samodzielnie zakupią osiem izraelskich radarów obserwacji sytuacji. Planowane jest też opracowanie kołowych i gąsienicowych transporterów opancerzonych dla sił zbrojnych V4. Nowy bojowy wóz piechoty byłby wspólnym produktem przemysłu obronnego wszystkich państw Grupy. Prowadzenie prac remontowych czy obsługowych miałoby być natomiast podzielone pomiędzy podmioty z poszczególnych państw na zasadzie wzajemności. Planowana jest również współpraca przy produkcji, amunicji średniego i dużego kalibru, eksploatacji niektórych platform lotniczych - chodzi głównie o samolot transportowy C-295M i śmigłowiec W-3 Sokół, opracowywanie systemów automatyzacji pola walki i wyposażenia indywidualnego żołnierza XXI wieku (Szopa, 2013).

Niezwykle istotnym aspektem strategicznej suwerenności współczesnego państwa jest bezpieczeństwo energetyczne. W tej kwestii Grupa Wyszehradzka ma zasadniczy problem. Całą czwórkę łączy uzależnienie od dostaw gazu z Rosji (Turowski, 2014, 
s. 113-114). Państwa V4 nie były w stanie stworzyć jednolitej wizji przynajmniej częściowego uniezależnienia się od monopolu Gazpromu; widoczna za to była tendencja do pogłębiania zależności importowej (Świątkowska, 2012, s. 159). Co prawda $\mathrm{w}$ ramach V4 podpisano istotne porozumienia dotyczące budowy wspólnego rynku gazu i energii elektrycznej, ale polityka poszczególnych państw Grupy zdawała się kwestionować te projekty. W tym wypadku brakowało zarówno konsekwencji, jak i woli. Sytuacja ta powoli ulega jednak zmianie. W państwach V4 rośnie świadomość faktu, że wspólne projekty energetyczne mogą dać realne i namacalne korzyści: nie tylko zwiększenie bezpieczeństwa, ale też możliwość negocjacji lepszych kontraktów z Moskwą.

Węgry z kolei coraz bardziej koncentrują się na współpracy w sektorze energetycznym z Federacją Rosyjską i - pomimo sprzeciwu Komisji Europejskiej - angażują się w budowę odcinka South Stream na swoim terytorium (Maciążek, 2014c). Gazociąg ma prowadzić z Rosji przez Morze Czarne do Bułgarii, a następnie do Serbii, na Węgry, do Austrii i Słowenii. Wstrzymanie rewersowych dostaw gazu na Ukrainę (oficjalnie do 2015 roku) czy problemy z oddaniem do użytku interkonektora ze Słowacją (Pokrywka, 2013, s. 39) również można odczytywać jako elementy realizowania interesów Gazpromu.

Państwa członkowskie V4 różni też poziom determinacji w realizacji inwestycji energetycznych. Jest to, podobnie jak w wypadku współpracy politycznej i wojskowej, pochodna różnych interesów i różnego spojrzenia na kwestie bezpieczeństwa w ogóle. Polska postrzega problem dywersyfikacji dostaw jako kluczowy dla swego bezpieczeństwa strategicznego (Zakrzewska, 2014, s. 169). Pojmuje go też w sposób faktyczny, tj. Warszawie zależy na tym, żeby zdywersyfikować nie kanały dostaw, ale dostawców gazu, czyli uniezależnić się od rosyjskiego Gazpromu. Inaczej do tego problemu podchodzą pozostałe państwa V4, widząc w nim bardziej kontekst ekonomiczny niż związany z kwestią bezpieczeństwa. Na Słowacji rozpowszechnione jest przekonanie o dużym znaczeniu tranzytowym V4 dla rosyjskiego gazu. Podkreśla się, że przez Słowację przebiega największy rurociąg przesyłowy gazu z Rosji do Niemiec. Jego techniczne możliwości przesyłu wynoszą ok. $90 \mathrm{mld} \mathrm{m}^{3}$ gazu rocznie z kierunku wschodniego. Jedynie tranzyt rosyjskiego gazu jest w stanie zapewnić rentowność istniejącej infrastruktury, a wymiana handlowa gazu na osi północ-południe lub z kierunku zachodniego na wschód nie będzie w stanie skompensować przychodów z dotychczasowej działalności. Prawdopodobnie tym należy tłumaczyć ostrożność Bratysławy w pracach nad połączeniami gazowymi z Polską i Węgrami (Turowski, 2012, s. 113). W Czechach źródeł bezpieczeństwa dostaw gazu upatruje się raczej w pełnej integracji czeskiego systemu przesyłowego z niemieckim. Gazociąg Opal biegnący od wybrzeża Morza Bałtyckiego do Czech, będący naziemną odnogą Nord Stream, jest postrzegany jako wzmocnienie bezpieczeństwa energetycznego i źródło dostaw rosyjskiego gazu na wypadek odcięcia przesyłu przez Ukrainę (Rosicki, Rosicki, 2012, s. 149, s. 155). Gazociąg ów został w zasadzie wybudowany celem ominięcia Ukrainy jako kraju tranzytowego dla rosyjskiego gazu. Obecnie Gazprom może użytkować 50 proc. przepustowości Opalu, jednak Rosjanie starają się o pozwolenie na jego pełne wykorzystywanie. Oddanie Moskwie kontroli nad gazociagiem Opal oraz budowa Nord Stream II są swoistymi probierzami solidarności energetycznej państw starej i nowej UE. Sukces tych przedsięwzięć poten- 
cjalnie rodzi szereg negatywnych zjawisk dla bezpieczeństwa energetycznego, a zatem również politycznego Europy Środkowej.

Pomimo powyższych różnic współpraca energetyczna V4 nabiera jednak coraz bardziej realnych kształtów. W dniu 31 października 2012 r. ministrowie gospodarki krajów Grupy Wyszehradzkiej podpisali w Warszawie porozumienie o integracji swoich systemów gazowych. Jego podstawowym elementem ma być planowany korytarz gazowy północ-południe. Gazociag ten jest kluczowy w kontekście wybudowanego w Świnnoujściu terminalu LNG, który docelowo będzie połączony infrastrukturą energetyczną z chorwackim terminalem Adria oraz planowanej budowy gazociagu pomiędzy Polską i Danią - Baltic Pippe. Docelowa przepustowość terminalu LNG $\left(7,5 \mathrm{mld} \mathrm{m}^{3}\right)$ i Baltic Pippe $\left(7 \mathrm{mld} \mathrm{m}^{3}\right)$ mają praktycznie zabezpieczyć potrzeby Polski po wygaśnięciu kontraktu jamalskiego z Gazpromem (2022 r.), a uwzględniając krajowe wydobycie ok. 4,4 $\mathrm{mld} \mathrm{m}^{3}$, pojawią się też możliwości eksportu gazu do partnerów z V4. Elementem powstającej infrastruktury mają być łączniki gazowe Polski z Czechami (przepustowość na osi północ-południe około $\left.5 \mathrm{mld} \mathrm{m}^{3}\right)$, Słowacją $\left(5,7 \mathrm{mld} \mathrm{m}^{3}\right.$, a docelowo $\left.9,5 \mathrm{mld} \mathrm{m}^{3}\right)$, Ukrainą $\left(8 \mathrm{mld} \mathrm{m}^{3}\right)$ i Litwą $\left(5 \mathrm{mld} \mathrm{m}^{3}\right)$. Potencjalnie mogą one zintegrować rynki środkowoeuropejskie w ramach projektu Korytarza Północ-Południe (Maciążek, 2014b). W perspektywie projekty mogą wydatnie zwiększyć bezpieczeństwo energetyczne krajów V4.

Inną inicjatywą która wyszła od państw Grupy Wyszehradzkiej, był wspólny list skierowany do Kongresu USA (marzec 2014 rok) o przyspieszenie eksportu gazu skroplonego (Turowski, 2014, s. 112). Inicjatywa ostatecznie zakończyła się sukcesem. Dnia 8 czerwca 2017 r. terminal w Świnoujściu odebrał pierwszą dostawę skroplonego gazu LNG amerykańskiej firmy Cheniere Energy. Amerykański gaz w istotny sposób narusza monopol Gazpromu w regionie. Włączenie USA w walkę o rynek gazu w Europie ma też swój wymiar strategiczny. Wpisuje się w koncepcje geopolityczne Stanów Zjednoczonych, które szukając rynku zbytów dla swego gazu jednocześnie osłabiają uzależnienie Europy Środkowej od surowca z Rosji. Potencjalnie jest to więc bardzo istotne uzupełnienie amerykańskiej obecności militarnej w regionie. Jest to także swoista gwarancja patronatu supermocarstwa nad energetycznymi i politycznymi projektami integracji regionu.

\section{Uwagi końcowe}

Po okresie wyraźnego wyhamowania wspólnych inicjatyw wydaje się, że V4 nabiera obecnie nowej dynamiki. Coraz wyraźniej rysuje się możliwość zbudowania północno-południowego korytarza gazowego, współpraca wojskowo-techniczna, chociaż nadal pozostaje w fazie projektów i uzgodnień, ma ulec intensyfikacji. Powstała grupa bojowa V4, państwa Grupy znalazły też wspólne płaszczyzny interesów politycznych. Zaczynają przemawiać jednym głosem w wielu kluczowych dla ich bezpieczeństwa kwestiach od kryzysu imigracyjnego w UE po protest wobec budowy Nord Stream II. Wspólnota interesów powoduje, że członkowie Grupy odzyskują poczucie, że region odgrywa istotną rolę w kształtowaniu rozwoju UE. Pozytywnym impulsem mogłoby być rozszerzenie V4 o państwa bałtyckie, Rumunię, Bułgarię, Słowenię. Mógł- 
by powstać relatywnie silny blok państw o podobnych oczekiwaniach względem UE i NATO, a tym samym istotny rozgrywający w politycznych rozgrywkach w Europie. Warunkiem byłoby jednak zachowanie funkcjonalnej jedności celów i metod. Barierą rozwoju V4 może być sytuowanie interesów Grupy w opozycji do polityki Berlina, podczas gdy realną siłę V4 mogłoby zapewnić właśnie włączenie Niemiec do wspólnych projektów.

Przyszłość państw V4 definiowana jest głównie przez pryzmat wspólnego rynku gazowego i elektrycznego dla Europy Środkowej, nowych możliwości handlu przez korytarze transportowe, których budowę V4 powinna forsować w UE, współpracę przemysłów obronnych i wyszehradzkiej grupy bojowej. Z pewnością pogłębiające się różnice potencjałów militarnych między Polską a pozostałymi krajami Grupy mogą utrudniać dalszą współpracę w kwestiach bezpieczeństwa, ale Warszawa jest otwarta na współpracę, co dobrze rokuje na przyszłość. Grupa Wyszehradzka powinna określać wspólne stanowiska w polityce energetycznej, w podejściu do zaopatrzenia w surowce (szczególnie gaz), walczyć o podobne podejście w stosunku do pakietu klimatycznego UE, być strukturą integrującą kraje ,nowej UE” wokół wspólnych celów. Państwa V4 mają potencjał by pełnić rolę, ,przewodnika” dla krajów ubiegających się o członkostwo w UE i NATO i wspierać ich politykę integracyjną. Ewentualne sukcesy lub porażki V4 w dużym stopniu będą jednak zdeterminowane przez politykę mocarstw wobec regionu, także w kontekście rywalizacji o wpływy oraz przez spójność lub jej brak wobec realnych wyzwań, politycznych wyborów i presji zewnętrznej.

\section{Bibliografia}

Bębenek B. (2014), Wyzwania inżynierii wojskowej, „Przegląd Sił Zbrojnych”, nr 2.

Ciupiński R. (2014), Zdolności wojskowe Unii Europejskiej. Perspektywy grup bojowych, „Rocznik Integracji Europejskiej" nr 8, DOI: 10.14746/rie.2014.8.8.

Czaputowicz J. (2013), Polityka bezpieczeństwa Polski - między samodzielnościq a europeizacja, e-Politikon" nr 6.

Czaputowicz J. (2014), Ewolucja polskiej polityki bezpieczeństwa: w kierunku strategicznej samodzielności?, „Studia Politologiczne”, vol. 34.

Czyż A. (2014), Grupa Wyszehradzka - 20 lat wspótpracy, „Athenaeum. Polskie Studia Politologiczne", vol. 42.

Gizicki W. (2014), Wybrane problemy wspólpracy wojskowej państw Grupy Wyszehradzkiej, „Athenaeum. Polskie Studia Politologiczne" vol. 42.

Gniazdowski M. (2012), Polska polityka w Grupie Wyszehradzkiej: paradoksy skali, „Polski Przegląd Dyplomatyczny”, nr 2 (64), Polski Instytut Spraw Międzynarodowych, Warszawa.

Gniazdowski M., Groszkowski J., Sadecki A. (2012), Państwa Grupy Wyszehradzkiej, w: W regionie siła? Stan i perspektywy wspótpracy wojskowej wybranych państw obszaru od Morza Bałtyckiego do Morza Czarnego, red. J. Gotkowska, O. Osica, OSW, Warszawa.

Gniazdowski M., Groszkowski J., Sadecki A., Wyszehradzka kakofonia wobec konfliktu rosyjskoukraińskiego, http://www.osw.waw.pl/pl/publikacje/analizy/2014-09-10/wyszehradzka-kakofonia-wobec-konfliktu-rosyjsko-ukrainskiego, 12.11.2014.

Grodzki R. (2015), Grupa Wyszehradzka i kryzys uchodźczy: solidarnie przeciw solidarności europejskiej?, „Biuletyn Instytutu Zachodniego”, nr 203, http://www.iz.poznan.pl/news/1271_ Wyszegrad_uchodzcy.pdf, 12.05.2016. 
Grudziński P. (2008), Państwo inteligentne. Polska w poszukiwaniu międzynarodowej roli, Toruń. http://www.lex.pl/akt/-/akt/m-p-2003-16-244, 19.11.2014.

http://www.msz.gov.pl/resource/ee1c8d3f-ff70-4283-87ba-8b1cc2c388cb, 10.11.2014.

Jankowski D. (2013), W stronę skutecznego minilateralizmu $w$ dziedzinie polityki bezpieczeństwa: przykładzie aktywności Polski w Grupie Wyszehradzkiej, „Biuletyn” PISM, nr III (27).

Joint Communiqué of the Ministers of Defence of the Visegrád Group, Litomierzyce, 4 maja 2012 r., http://www.mon.gov.pl/pliki/File/dok1.pdf, 13.09.2014.

Kałan D. (2014), Mieć czy być: unijne sankcje wobec Rosji jako dylemat V4, „PISM Biuletyn”, nr 103 (1215).

Kubin T. (2014), Grupa Wyszehradzka - perspektywy dalszej wspólpracy, „Athenaeum. Polskie Studia Politologiczne", vol. 42.

Kupiecki R. (2016), Organizacja Traktatu Pólnocnoatlantyckiego, Warszawa.

Kużelewska E., Bartnicki A. R., Skarzyński R. (2015), Origins of and perspectives for the future for the Visegrad Group, w: Ten Years of the Visegrad Group Members States in the European Union, red. A. Piekutowska, I. Wrońska, Warsaw-Białystok.

Lorenz W. (2013), Grupa bojowa UE - szansa na przełom we wspótpracy Grupy Wyszehradzkiej?, „Biuletyn” PISM, nr 38 (1014).

Maciążek P. (2016), Polska gazowym hubem Europy Środkowej. „Irytacja zwolenników Nord Stream 2", http://energetyka.defence24.pl/372044,polska-gazowym-hubem-europy-srodkowejirytacja-zwolennikow-nord-stream-2, 18.05.2016.

Maciążek P. (2014a), Pogłębia się izolacja Polski w Grupie Wyszehradzkiej. Budapeszt, Praga i Bratystawa nie chca prowokować Rosji, „Defence24”.

Maciążek P. (2014b), Putin nagradza Orbana za wierność, „Defence24”.

Maciążek P. (2014c), South Stream na Węrzech mimo sprzeciwu UE, „Defence24”.

Palowski J. (2014), Polska nadal w programie wspólnego radaru 3D Grupy Wyszehradzkiej „Defence24".

Pokrywka Ł. (2013), Planowane inwestycje w zakresie infrastruktury gazowej w Polsce, w: Analiza infrastruktury gazowej $w$ Polsce z perspektywy przyszłych wyzwań energetycznych i rozwoju sektora gazu niekonwencjonalnego, red. I. Albrecht, Instytut Kościuszki, Kraków.

Pronińska K. (2013), Wpływ wspótpracy energetycznej krajów Europy Środkowej na regionalne bezpieczeństwo energetyczne i politykę energetycznq UE, „Zeszyty Natolińskie”, $\mathrm{nr} 51$.

Raport polskiego przewodnictwa w Grupie Wyszehradzkiej lipiec 2012-czerwiec 2013 (2013), red. P. Bajda, Warszawa.

Rosicki R., Rosicki G. (2012), Znaczenie gazociagu Nord Stream dla Polski, „Przegląd Bezpieczeństwa Wewnętrznego", nr 6.

Sobczyk K. (2011), Wspótpraca państw Europy Środkowo-Wschodniej w dziedzinie bezpieczeństwa energetycznego, „Bezpieczeństwo Narodowe”, nr 20 (IV).

Swora M. (2011), Bezpieczeństwo energetyczne - sieci energetyczne, w: Raport: W kierunku nowoczesnej polityki energetycznej. Energia elektryczna, red. M. Swora, Instytut Obywatelski, http://www.instytutobywatelski.pl/wp-content/uploads/2011/08/internet_bez_spadow_z_ okladka_bezpieczen\%CC\%81 stwo-dostaw-energii-elektrycznej.pdf, 12.05.2016.

Szopa M. (2013), Modernizacja polskiej armii wspólnie z Grupq Wyszehradzka?, „Defence24”.

Świątkowska J. (2012), Bezpieczeństwo energetyczne jako fundament współczesnego bezpieczeństwa narodowego Polski, „Annales Universitatis Paedagogicae Cracoviensis, Studia Politologica", nr VIII.

Turowski P. (2014), Bezpieczeństwo dostaw gazu dla Grupy Wyszehradzkiej i pozostałych państw Unii Europejskiej, „Bezpieczeństwo Narodowe” II, nr 3. 
Zakrzewska O. (2014), Bezpieczeństwo energetyczne w stosunkach Rosja - Unia Europejska w kontekście wspótzależności eksportowo-importowych, „Kolegium Ekonomiczno-Społeczne”, nr 1(17).

Zieliński T. (2013), Inicjatywa Smart Defence szansq na zwiększenie zdolności obronnych NATO?, w: NATO wobec wyzwań wspótczesnego świata, red. R. Czulda, R. Łoś, J. Reginia-Zacharski, Warszawa-Lódź.

Иванов И. (2002), Новая Российская дипломатия, ОЛМА-ПРЕСС, М.

Примаков Е. М. (1999), Годы в большой политике, Совершенно секретно, М.

\section{Streszczenie}

Artykuł poddaje analizie ramy współpracy państw Grupy Wyszehradzkiej, problemy jej funkcjonowania w obliczu nowych wyzwań bezpieczeństwa w Europie. Podejmuje próbę nakreślenia perspektyw organizacji w zmieniającym się środowisku geopolitycznym i wskazania obszarów, w których współpraca między państwami V4 układa się dobrze. Omawiane są kwestie wspólnego rynku gazowego i elektrycznego dla Europy Środkowej, różnice potencjałów militarnych oraz pozycji zajmowanej przez V4 w UE.

Słowa kluczowe: Grupa Wyszehradzka, V4, bezpieczeństwo, współpraca

\section{The Visegrad Group - new challenges to security and cooperation prospects}

\section{Summary}

The article analyzes the framework of cooperation between the Visegrad Group countries and the challenges of new dimension of security in Europe. It tries to describe the prospects for the organization in a changing geopolitical environment and identify areas of successful cooperation between V4 countries. There are also discussed the issues of common market in gas and electricity in Central Europe, differences of military potentials and the position occupied by the $\mathrm{V} 4$ in the EU.

Key words: Visegrad Group, V4, security, cooperation 
